\title{
Glottic Cancer pT4b TNM Finding v6
}

National Cancer Institute

\section{Source}

National Cancer Institute. Glottic Cancer pT 4b TNM Finding v6. NCI Thesaurus. Code C64679.

Glottic cancer with tumor invading prevertebral space, encasing carotid artery, or invading mediastinal structures. (from AJCC 6th Ed.) 